\title{
Interdependence Between the Belgrade Stock Exchange Development and Serbia's Economic Growth
}

Article history:

Received: 1 November 2019

Sent for revision: 12 November 2019

Received in revised form: 11 December 2019

Accepted: 12 December 2019

Available online: 31 December 2019

Abstract: The goal of this research is to conduct an empirical test to determine the interdependence between the Belgrade Stock Exchange development and Serbia's economic growth. The authors of this paper used the quarterly data about the market capitalization and turnover of shares achieved at the Belgrade Stock Exchange, as well as the quarterly data about Serbia's gross domestic product between 2003 and 2018. During the testing of the long-term variable interconnection the Johansen (1991) co-integration test was used, whereas the Granger causality test was used for the causality analysis. The test results to date primarily show that the development of a capital market is of significance for economic growth, which implies that a liquid stock exchange may serve as a reliable indicator of a long-term growth of economic activity.

Keywords: Belgrade Stock Exchange, Turnover of Shares, Market Capitalization, Economic Growth, Granger Causality Test.

\section{Međuzavisnost između Beogradske berze i ekonomskog rasta Srbije}

Apstrakt: Cilj studije jeste empirijsko ispitivanje međusobne uslovljenosti razvoja Beogradske berze i ekonomskog rasta Srbije. U radu su korišćene kvartalne vrednosti tržišne kapitalizacije $i$ ostvarenog prometa akcijama na Beogradskoj berzi i kvartalne vrednosti bruto domaćeg proizvoda Srbije u

\footnotetext{
${ }^{1}$ University of Kragujevac, Faculty of Economics, dstojkovic@kg.ac.rs

${ }^{2}$ University of Kragujevac, Faculty of Economics

${ }^{3}$ Financial markets consultant
} 
Stojković D. et al.: Interdependence Between the Belgrade Stock Exchange...

periodu 2003-2018. Prilikom ispitivanja dugoročne povezanosti varijabli, korišćen je Johansen (1991) test kointegracije, dok se u analizi kauzalnosti koristio Granger Causality Test. Rezultati dosadašnjih istraživanja su uglavnom pokazali da je razvoj tržišta kapitala od značaja za ekonomski rast, što implicira da likvidna berza može biti pouzdan indikator dugoročnog rasta ekonomske aktivnosti.

Ključne reči: Beogradska berza, promet akcijama, tržišna kapitalizacija, ekonomski rast, Granger Causality Test.

\section{Introduction}

The main role of a capital market reflects in savings collection and provision of funds to companies which need to invest them in their manufacturing equipment and new plants (Baldwin \& Wyplosz, 2010, 548). By stimulating accumulation, capital markets make an important role in the stimulation of a long-term economic growth. In the event of a need for additional funds, companies may acquire capital by borrowing from commercial banks, or they may acquire it by selling their bonds and/or shares on the capital market. The financial systems of a multitude of countries are dominated by banks, at least those with a dominant role in loan provision and savings collection. However, even though there are numerous examples of successful banc-centric financial systems (e.g. China and Germany), modern conditions dictate a significant development of market-dominated systems. This means that issuers sell their securities on an open market and so acquire the required funds. The UK and US financial systems are the finest examples of direct financing.

The capital market in Serbia is still underdeveloped, which is why companies mainly rely on bank loans. The private companies in the observed area are mostly unwilling to "open", which would lead to the diversification of their ownership structures (Marinković, Ljumović \& Stojković, 2012). At the end of 2018 the first initial public offer was launched in Serbia after 78 years (Fintel energija a.d.). Also, mistrust in the stock exchange and unwillingness of individuals to make more considerable investments in shares quoted at the Belgrade Stock Exchange prevail in Serbia. By comparison, in the USA the households (individuals) are dominant with regards to purchase of shares as opposed to other investors (Rose \& Marquis, 2011, 661).

The main goal of this paper is an empirical test to determine the interdependence between a capital market and economic growth illustrated by the example of the Republic of Serbia. The Serbian capital market has been experiencing a decreasing turnover since 2008 , as well as less public and investment companies. In terms of organization and regulation, developed 
Stojković D. et al.: Interdependence Between the Belgrade Stock Exchange...

market standards have been met, but a low level of investors' trust still remains the major issue. The Granger causality test was selected as a suitable methodology framework for the determination of the interdependence between the capital market and real economy sector and the Johansen test was applied for co-integration testing. The paper structure is as follows: the introductory notes are first followed by the overview of relevant studies dealing with this problem, and then by a more detailed description of the data and research methodologies, whereas the empirical result is presented separately. Finally, the concluding considerations provide recommendations for the holders of economic policy in Serbia.

\section{Literature Overview}

The link between the development of the financial stock market and economic growth has been attracting the attention of many researchers. Pan and Mishra (2018) drew an interesting conclusion that the global crisis had significantly affected China's real and financial sector. Furthermore, the authors emphasized that the Shanghai $A$ market had a negative impact on its economic growth, most likely due to its irrational prosperity, i.e. lack of economic bubbles in China's financial systems. The empirical research included 36 African countries and established that the countries with markets underwent faster development than those without them (Ngare, Nyamongo \& Misati, 2014). Owing to the stock market, companies may more quickly obtain the capital required for investments under more favorable terms, which encourages economic growth. Caporale et al. (2004) used the example of 7 countries to illustrate that a well-developed capital market was a prerequisite for economic growth. Also, the research about India proved that its capital market had a considerable impact on its economic growth (Mishra et al, 2010). Contrarily, Vazakidis \& Adamopoulos (2009) found that economic growth also instigated stock exchange development on a long-term basis. Similarly, Luintel and Khan (1999) studied a sample of ten developing countries and proved the existence of correlation between the stock exchange development and economic growth. Turkey served as an example that there was a cointegration relationship between the capital market development indicators and economic growth (Coşkun et al., 2017). Adamopoulos (2010) made a similar conclusion by studying the above relationship in Ireland. The research conducted by Levine and Zervos (1998) confirmed and statistically proved a strong relationship between the initial stock exchange development and resultant economic growth. Also, in Malaysia it was determined that there was a positive and statistically relevant connection between the stock exchange development and economic growth on a long-term basis (Nordin \& Nordin, 2016). 
Stojković D. et al.: Interdependence Between the Belgrade Stock Exchange...

There is, therefore, the connection between the development of financial stock exchanges and economic growth that has been attracting the attention of numerous researchers. Some of them view the stock exchanges separately (Guryay, Safakli \& Tuzel, 2007; Baboo \& Odit 2009; Boubakari \& Ognaligui, 2010; Shahbaz, Ahmed \& Ali, 2008), while some view them jointly (Levine \& Zervos, 1996; Demetriades \& Hussein, 1996; Boubakari \& Jin, 2010; Aboudou, 2010). Some authors only found a long-term causal relation between stock exchange development and economic growth (Atje \& Jovanović, 1993; Shahbaz, Ahmed \& Ali, 2008; Bahadur \& Neupane, 2006; Boubakari \& Jin, 2010), whereas a number of them established the existence of such connection on a short-term basis as well (Baboo \& Odit, 2009; Aboudou, 2010). Contrary to the authors above, Carp (2012) did not establish a causal relation between market capitalization and economic growth in the example of Romania.

\section{Data and Methodology Description}

The Belgrade Stock Exchange was founded in 1894, but it ceased operating for almost half a century. It stopped operating in 1941, but formally existed until 1953, when it was abolished by the Decision of the Presidium of the Serbian Government (Dugalić \& Štimac, 2014). The Belgrade Stock Exchange was only reestablished in 1989. Nevertheless, up until 2002 the Stock Exchange dealt with short-term securities and money. The largest portion of its turnover during 2000, 2001 and 2002 was made of commercial and treasury bills (excluded from trade in 2004). Although the first share trade was made in 1991, a great progress in the market share trade was made only in 2000. At that point, shares from previous privatization processes were included in secondary trading. Privatization in Serbia forced all public (open) joint stock companies to come out on the market (Law on Privatization, Art. 59). This resulted in a huge number of companies in the Belgrade Stock Exchange in 2005, 2006 and 2007. At the onset of 2008 nearly 2000 shares were quoted on the Stock Exchange. However, the shares were poorly traded and over time their number decreased mostly for two reasons: initiated bankruptcy proceedings over companies or termination of their public joint stock company status.

A more intensive long-term securities trade on the Belgrade Stock Exchange began in 2001. Between 2001 and 2007 the capital market in the Republic of Serbia made progress under the conditions of high international liquidity and globally growing interest in emerging market and frontier market investments (Rakočević, 2016). In 2007 this produced the best results of the Belgrade Stock Exchange operation ever. The fast development of the Belgrade Stock Exchange in 2005, 2006 and 2007 was disrupted by the global financial crisis 
Stojković D. et al.: Interdependence Between the Belgrade Stock Exchange...

in 2008. Unlike developed markets, which generally managed to get back on the track, the Belgrade Stock Exchange has still been searching for proper solutions to its problems. It is characterized by a dominant government bond trade (approximately $85 \%$ of the total turnover in 2016 and 2017) and very low share liquidity. At the end of 2018 approximately 600 shares were quoted on the Belgrade Stock Exchange.

This empirical research uses the quarterly data about achieved share turnover (TURNOVER), share market capitalization (CAP) and real gross domestic product (GDP) of Serbia between the third quarter of 2003 and first quarter of 2018. Figures 1 and 2 contain a graphic presentation of the achieved share turnover and market capitalization trends in a logarithmic form (L). The logarithmic values of the Serbian GDP are expressed in Figure 3.

Figure 1. Turnover at Belgrade Stock Exchange (logarithm scale)

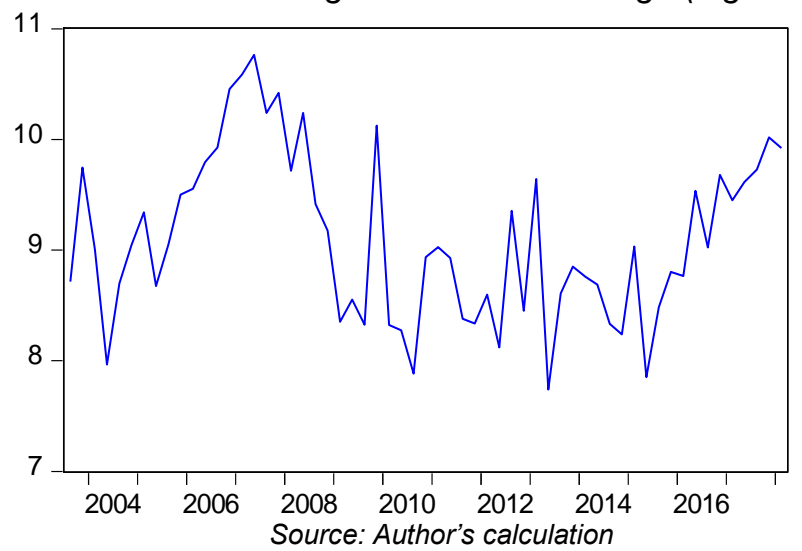

Figure 2. Market capitalization at Belgrade Stock Exchange (logarithm scale)

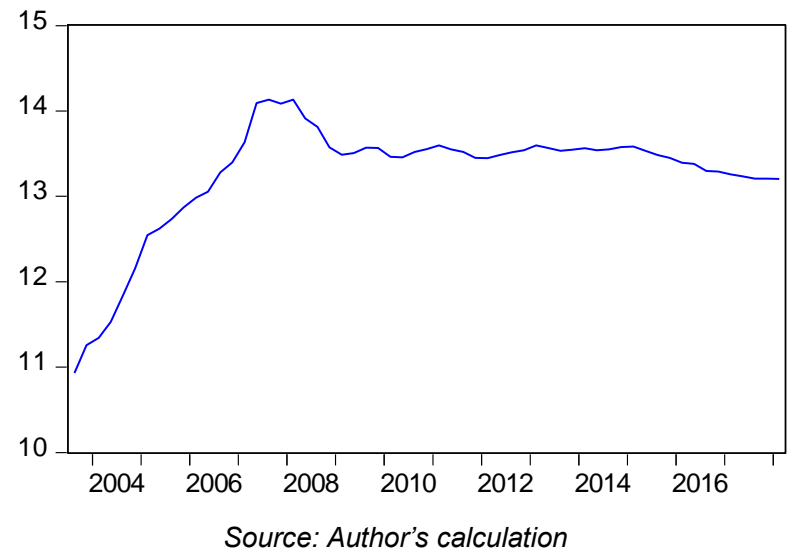

Industrija, Vol.47, No.4, 2019 
Stojković D. et al.: Interdependence Between the Belgrade Stock Exchange...

Figure 3. GDP in Serbia (logarithm scale)

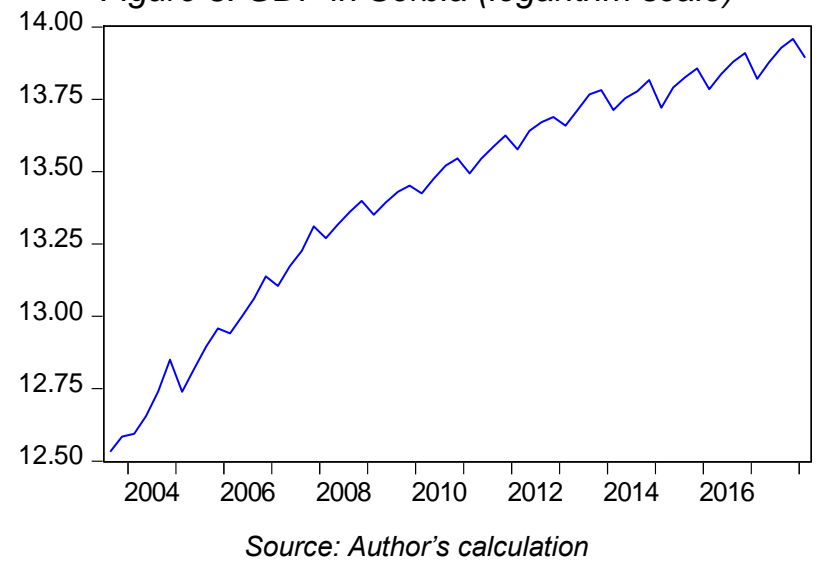

The traditional ADF test is used to determine whether the time series is stationary or not (Dickey \& Fuller, ADF, 1981). The ADF test starts with $\mathrm{HO}$ : a time series has a unit root (non-stationary). The Johansen co-integration test is used to define a long-term interconnection of the variables. The basic preconditions for the utilization of the Johansen (1991) test are that the variables are non-stationary at the level and that they are stationary upon conversion into first difference. Trace statistics and maximum characteristic statistics are used to establish rank. The interdependence between the Belgrade Stock Exchange development and Serbia's economic growth is analyzed by means of the Granger causality test (Granger, 1969). This method is used to test the causal relation between two variables. It indicates that, if the past values of variable $\boldsymbol{y}$ significantly contribute to variable $\boldsymbol{x}$ value prediction, then $\boldsymbol{y}$ Granger-causes $\boldsymbol{x}$. Contrarily, if the past values of variable $\boldsymbol{x}$ statistically improve the prediction of variable $\boldsymbol{y}$, then $\boldsymbol{x}$ Granger-causes $\boldsymbol{y}$. The test is based on the following regression:

$$
\begin{aligned}
& y_{t}=\beta_{0}+\sum_{k=1}^{M} \beta_{\mathrm{k}} \mathrm{y}_{\mathrm{T}-\mathrm{k}}+\sum_{l=1}^{N} \alpha_{1} \mathrm{x}_{\mathrm{T}-\mathrm{l}}+\mathrm{y}_{\mathrm{T}} \\
& x_{t}=\gamma_{0}+\sum_{k=1}^{M} \delta_{\mathrm{k}} \mathrm{y}_{\mathrm{T}-\mathrm{K}}+\sum_{l=1}^{N} \gamma_{1} \mathrm{x}_{\mathrm{T}-1}+\mathrm{v}_{\mathrm{T}}
\end{aligned}
$$

Where $y_{t}$ and $x_{t}$ are two variables, $\mathrm{y}_{\mathrm{T}}$ and $\mathrm{v}_{\mathrm{T}}$ are mutually uncorrelated error terms, $t$ denotes a time period and $k$ and $/$ denote a number of lags.

The zero hypothesis is $\alpha_{1}=0$ for each $/$ and $\delta_{\mathrm{x}}=0$ for each $k$, in opposition to the alternative hypothesis that $\alpha_{1} \neq 0$ and $\delta_{\mathrm{K}} \neq 0$ for at least some $/$ and $k$. 
Stojković D. et al.: Interdependence Between the Belgrade Stock Exchange...

If coefficient $\alpha_{1}$ is statistically significant (reliable), and $\delta_{\mathrm{K}}$ is not, then $x$ causes $y$. In the opposing case $y$ causes $x$. If both coefficients, $\alpha_{1}$ and $\delta_{x}$, are significant (reliable), then the causality is mutual. In order to test the hypothesis, the F-test is applied as follows:

$$
F=\frac{\left(\mathrm{RSS}_{\mathrm{r}}-\mathrm{RSS}_{\mathrm{y}}\right) / l}{\mathrm{RSS}_{\mathrm{y}} /(\mathrm{T}-2 l-1)}
$$

Where:

- RSS $_{\mathrm{r}}$ - restricted residual sum of squares,

- $\mathrm{RSS}_{\mathrm{y}}$ - unrestricted residual sum of squares,

- T-number of observations,

- I- number of lags,

- $(\mathrm{T}-2 l-1)$ - number of degrees of freedom.

The common hypothesis for all equations is that $\beta_{1}=\beta_{2}=\ldots=\beta_{l}=0$. The zero hypothesis is that $\boldsymbol{x}$ does not Granger-cause $\boldsymbol{y}$ in the first regression and that $\boldsymbol{y}$ does not Granger-cause $\boldsymbol{x}$ in the second regression (Granger, 1969). The Granger test analyzes the zero hypothesis ( $\mathrm{H} 0)$ that there is no causal relation. If $(\mathrm{HO})$ is rejected with its statistical significance, it may be concluded that the tested direction is characterized by causality. After that, the test is conducted in the contrary direction to establish whether there is causality between the two variables in the above direction as well. For each pair of variables there are two zero hypotheses to be tested. The test results are sensitive to the tested time lags, therefore the procedure must be repeated as many times as necessary to find an appropriate lag length.

\section{Empirical Results}

In order to ensure the robustness of results, the empirical analysis starts testing the existence of a unit root of the relevant variables. Stationarity testing is of great importance prior to the application of the causality or cointegration tests. The ADF test results are shown in Table 1. According to the test results, it is obvious that the variables possess a unit root, which means that they are not stationary at the level. Upon their conversion into first difference, they become stationary. Consequently, it may be stated that the order of integration of LGDP, LTURNOVER and LCAP is I(1). In this manner the necessary prerequisite for the conducting of the Johansen co-integration test has been met. Table 2 shows the Johansen co-integration test results. Since the lag length mainly determines the co-integration test results, particular attention has been drawn to its optimal value selection. The optimal lag $k$ is selected based on the formulation of the VAR model, which is 
Stojković D. et al.: Interdependence Between the Belgrade Stock Exchange...

characterized by a lack of autocorrelation, heteroscedasticity or distribution of residuals which tend towards normality. Based on the VAR model results, the appropriate lag in the Johansen methodology corresponds to $k-1$. The optimal lag length is 3 periods (in the VAR model it is 4), as may be observed. The results of the trace statistics and Max-Eigen statistics unequivocally show a presence of one co-integration vector between the relevant variables.

Table 1. Unit root test results

\begin{tabular}{|l|l|c|}
\hline \multicolumn{1}{|c|}{ Variable } & \multicolumn{1}{|c|}{ Deterministic component } & ADF test (number of lags) \\
\hline LGDP & Constant \& trend & $-2.386(0)$ \\
\hline LCAP & Constant & $-3.27(1)$ \\
\hline LTURNOVER & Constant & $-2.09(1)$ \\
\hline \multicolumn{2}{|c|}{ First difference } \\
\hline LGDP & Constant \& trend & $-5.42(1)^{*}$ \\
\hline LCAP & Constant & $-3.976(0)^{*}$ \\
\hline LTURNOVER & Constant & $-13.366(0)^{*}$ \\
\hline Remark: ${ }^{*}$ and ${ }^{* *}$ show significance at $1 \%$ and 5\% level, respectively. \\
\hline
\end{tabular}

Source: Author's calculation.

Table 2. Johansen test results

Republic of Serbia; Deterministic component: V_2005Q1 V_2007Q2; VAR(4); Lag (k-1)

\begin{tabular}{|l|c|c|c|c|}
\hline Null hypothesis & Trace statistic & $\begin{array}{c}\text { Critical value } \\
(5 \%)\end{array}$ & Max-Eigen value & $\begin{array}{c}\text { Critical value } \\
(5 \%)\end{array}$ \\
\hline $\mathrm{H}_{0}: \mathrm{r}=0$ & 55.12185 & 29.79707 & 43.89434 & 21.13162 \\
\hline $\mathrm{H}_{0}: \mathrm{r}=1$ & 11.22751 & 15.49471 & 10.95626 & 14.26460 \\
\hline $\mathrm{H}_{0}: \mathrm{r}=2$ & 0.271255 & 3.841466 & 0.271255 & 3.841466 \\
\hline
\end{tabular}

Source: Author's calculation.

The results of the VECM Granger causality test are shown in Table 3.

Table 3. VECM causality test results

\begin{tabular}{|l|c|c|c|c|}
\hline Dependent variable & \multicolumn{4}{|c|}{ Type of causality } \\
\hline & \multicolumn{4}{|c|}{ Short- run } \\
\hline & $\Delta \mathrm{LGDP}_{\mathrm{t}}$ & $\Delta \mathrm{LTURNOVER}_{\mathrm{t}}$ & $\Delta \mathrm{LCAP}_{\mathrm{t}}$ & $\mathrm{ECT}_{\mathrm{t}-1}$ \\
\hline$\Delta \mathrm{LGDP}_{\mathrm{t}}$ & - & 0.87 & 11.44 & 15.01 \\
& & $(0.83)$ & $(0.00)$ & $(0.02)$ \\
\hline$\Delta \mathrm{LTURNOVER}_{\mathrm{t}}$ & 2.41 & - & 4.20 & 5.13 \\
& $(0.49)$ & & $(0.24)$ & $(0.53)$ \\
\hline$\Delta \mathrm{LCAP}_{\mathrm{t}}$ & 9.47 & 1.65 & - & 13.41 \\
& $(0.02)$ & $(0.65)$ & & $(0.04)$ \\
\hline
\end{tabular}

Source: Author's calculation. 
Stojković D. et al.: Interdependence Between the Belgrade Stock Exchange...

There are two established causal relations between the variables. The observed causality is bidirectional, which implies that the market capitalization changes lead to the economic growth changes and that the economic growth changes lead to the market capitalization changes.

\section{Concluding Considerations}

In this paper the authors search for the connection between the economic growth, market capitalization and share turnover in the Republic of Serbia. The observational time horizon is Q3 2003 - Q1 2018. The co-integration test and proper VECM Granger causality test have been used to determine the causality. The co-integration test results have proven that the variables have a long-term connection, which means they share a common stochastic trend. In addition, the Granger causality test results have shown that there is a bilateral causality between the market capitalization trends and gross domestic product. However, market liquidity is much more important for economic growth and development of a capital market than market size. A liquid stock exchange may be a reliable indicator of future long-term economic growth. It ensures a necessary liquidity for the investors, provides an exit mechanism for venture capital, allows companies to obtain the necessary capital and provides information about the quality of potential investments. Nevertheless, in the example of Serbia no significant connection has been established between the achieved share turnover and economic growth. In this respect, it may be concluded that the Belgrade Stock Exchange presents no essential factor for the development of the Serbian economy.

\section{References}

Aboudou, M. T. (2010). Stock market development and economic growth: the case of West African Monetary Union. International Journal of Economics and Finance, 2(3), 97-103.

Adamopoulos, A. (2010). Financial development and economic growth: an empirical analysis for Ireland. International Journal of Economic Sciences and Applied Research, 3(1), 75-88.

Atje, R. \& Jovanovic, B. (1993). Stock markets and development. European Economic Review, 37 (2-3), 632-640.

Baboo, M. N. \& Odit M. P. (2009). Stock market development and economic growth: The case of Mauritius. International Business \& Economics Research Journal, 8(2), 77-88.

Bahadur \& Neupane, (2006). Stock market and economic development: a causality test. The Journal of Nepalese Business Studies, 3(1), 36-44. 
Stojković D. et al.: Interdependence Between the Belgrade Stock Exchange...

Boldvin, R. \& Viploš, Č. (2010). Ekonomija evropskih integracija, Belgrade: Data Status, Beograd, translated edition: Baldwin, R. \& Wyplosz, C. (2009) The Economics of European Integration, McGraw-Hill Education.

Boubakari, A. \& Jin, D. (2010). The role of stock market development in economic growth: Evidence from some euronext countries. International Journal of Financial Research, Sciedu Press, 1(1), 14-20.

Boubakari, A. \& Ognaligui, R. (2010). Financial stock market and economic growth in developing countries: the case of Douala Stock Exchange in Cameroon. International Journal of Business and Management, 5(5), 82-88.

Caporale, G.M., Howells, P., Soliman, A. (2004). Stock market development and economic growth: The causal linkage. Journal of Economic Development, 29(1), 33-50.

Carp, L. (2012). Can stock market development boost economic growth? Empirical evidence from emerging markets in Central and Eastern Europe. Procedia Economics and Finance, 3, 438-444.

Coşkun, Y., Seven, Ü., Ertuğrul, H. M. \& Ulussever, T. (2017). Capital market and economic growth nexus: Evidence from Turkey. Central Bank Review, 17(1), 1929.

Demetriades, P. \& Hussein, K. (1996). Does financial development cause economic growth? Time-series Evidence from 16 Countries, Journal of Development Economics, 51(2), 387-411.

Dickey D. A. \& Fuller W. A. (1979). Distribution of the estimators for the autoregressive time series with a unit root. Journal of American Statistical Association, 74, 427431.

Dugalić, V. \& Štimac, M. (2014). Basics of stock exchange business ( $8^{\text {th }}$ ed). Belgrade: Čugura print.

Granger, C. W. J. (1969). Investigating causal relations by econometric models and cross-spectral methods. Econometrica, 37(3), 424-438.

Güryay, E., Şafakli, O. V. \& Tüzel, B. (2007), Financial development and economic growth: Evidence from northern Cyprus. International Research Journal of Finance and Economics, 8, 57-62.

Johansen S. (1991). Estimation and hypothesis testing of Cointegration vector in Gaussian vector autoregressive models. Econometrica, 59, 1551-1580.

Law on Privatization, RS Official Gazette, no. 38/2001, 18/2003 and 45/2005.

Levine, R. \& Zervos, S. (1996). Stock market development and long run growth. World Bank Economic Review, 10(2), 323-339.

Levine, R. \& Zervos, S. (1998). Stock markets, banks and economic growth. American Economic Review, 88(3), 537-558.

Luintel, B. and Khan, M. (1999). A quantitative reassessment of the finance growth nexus: evidence from a multivariate VAR, Journal of Development Economics, 60(2), 381-405.

Marinković, S., Ljumović, I., Stojković, D. (2012). Going public and initial public offering: an exploratory study of motives from Serbian companies, Industrija, 2, 125-143.

Mishra, P.K., Sankar Mishra, U., Ranjan Mishra, B. \& Mishra, P. (2010). Capital market efficiency and economic growth: The case of India. European Journal of Economics, Finance and Administrative Sciences, 27, 130-138.

Ngare, E., Nyamongo, M. E. \& Misati, R. N. (2014). Stock market development and economic growth in Africa. Journal of Economics and Business, 74, 24-39. 
Stojković D. et al.: Interdependence Between the Belgrade Stock Exchange...

Nordin, S. \& Nordin, N. (2016). The impact of capital market on economic growth: A Malaysian outlook. International Journal of Economics and Financial Issues, 6, (7S), 259-265.

Pan, L., Mishra, V. (2018). Stock market development and economic growth: Empirical evidence from China. Economic Modelling, 68, 661-373.

Rakočević R. (2016) Foreign investors' influence on the Serbian stock market. Bankarstvo, 45(3), 14-35.

Rose, S. P. \& Marquis, H. M. (2011). Financial Institutions and Markets $\left(11^{\text {th }} \mathrm{ed}\right.$.). New York: McGraw-Hill Irwin (translated edition).

Shahzab, M., Ahmed, N. \& Ali, L. (2008). Stock market development and economic growth: ARDL causality in Pakistan. International Research Journal of Finance and Economics, 14, 182-195.

Vazakidis, A. and Adamopoulos, A. (2009). Stock market development and economic growth. American Journal of Applied Sciences, 6(11), 1932-1940. 